1 Supplementary Information

\title{
Arsenic in groundwater: the deep Late Pleistocene aquifers of the western Bengal Basin.
}

\author{
J.M. McArthur ${ }^{a \star}$, U. Ghosal' ${ }^{\mathrm{b}}$, P.K. Sikdar ${ }^{\mathrm{b}}$, Jim Ballc \\ aDepartment of Earth Sciences, University College London, Gower Street, LondonWC1E 6BT, UK. \\ bepartment of Environment Management, Indian Institute of Social Welfare and Business \\ Management, College Square (West), Kolkata-700073, India. \\ 'School of Environmental Science, University of Liverpool, Brownlow Street, Liverpool L69 3GP.
}

17 pages including Table $\mathrm{S} 1$

6 figures

1 table

S1. History of the Bengal Basin, 125 ka to Now. The sedimentology of the aquifers of the Bengal Basin is summarized from Refs. 1 - 9. In outline, sea level declined by some $120 \mathrm{~m}$ between $125 \mathrm{ka}$ and $18 \mathrm{ka}$, the time of the last glacial maximum $(\mathrm{LGM})^{10}$. During the decline, the coastline retreated southward by up to $100 \mathrm{~km}^{5,6,11}$. The existing and newly-exposed coast, and the low-lying hinterland, was eroded into a landscape of interfluves and river channels with a relief of mostly no more than $50 \mathrm{~m}^{3,4,8}$. The pre-LGM sediments, predominantly sands, beneath the interfluves were weathered in the zone of most active groundwater flow, largely the unsaturated zone down to depths level with river bases, which was generally no more than $30 \mathrm{~m}$ depth. The weathering formed the oxidised brown Pleistocene sands that now sit on underlying grey Pleistocene sands that were weathered much less. A reddish-brown clay palaeosol formed on top of the brown, weathered sand, and has been termed a laterite ${ }^{3,4}$ and the 'last glacial maximum palaeosol', or LGMP'2.

Sea level rose after the termination of the LGM, stabilising around $6 \mathrm{ka}$ close to the present level. The rise created the accommodation space for the accumulation of post-LGM sediments, largely sands, on top of the LGM landscape to form the present submarine and subaerial deltas, under which lies the buried landscape of palaeo-interfluves and palaeo-channels. River avulsion since $6 \mathrm{ka}$ has reworked the upper $20-30 \mathrm{~m}$ of the sequence, leaving large areas covered by shallow palaeo-channel fill of grey sands to $20-30 \mathrm{~m}$ depth, interspersed with silty/clayey/peaty floodplain sequences ${ }^{8,13-15}$. Historical floodplain silts now cover the succession in the basin's south and central parts, forming an upper, semi-confining aquitard of fine sediments usually $<5 \mathrm{~m}$ thick.

Across the Bengal Basin, the LGM land-surface that separates pre- and post-LGM aquifers lies at a depth that depends on location. It has been customary to separate the 'deep' aquifers from the 'shallow' aquifers of the Bengal Basin using a practical division based on a maximum sea-level lowering of $120 \mathrm{~m}$. In the light of both old ${ }^{1}$ and recent ${ }^{9,14,16}$ results on sedimentology and dating in the Bengal Basin, that figure is no longer tenable. For example, around the basin margin, the pre-LGM surface crops out, as do pre-LGM aquifers. Additionally, across much of the basin interior, the LGM surface lies at 30-40 m depth where palaeo-interfluves are preserved in the subsurface, and at depths between 50 and $120 \mathrm{~m}$ depth in the far smaller areas underlain by palaeo-channels. ${ }^{1-4,8,8,12-15,17-21}$

At the LGM, the depth of river incision, relative to today's ground surface, would have been greatest at the coast and been close to the sea-level lowering of around $120 \mathrm{~m}$ below present sea-level, which would be around $130 \mathrm{~m}$ below present ground level in our area where elevations are currently no more than $10 \mathrm{~m}$ above sea-level. Our area was $>100 \mathrm{~km}$ from the coast at that time ${ }^{5,6,11}$ so the depth of river incision in our field area would have been less than $120 \mathrm{~m}$ and probably no more than $70 \mathrm{mbgl}$ on the basis of our drilling information ${ }^{15}$ and inferences from the cross-sections of Refs. 3 and 4. For an area some $50 \mathrm{~km}$ south of our study area, a depth to the LGM surface ${ }^{15}$ is around $50 \mathrm{~m}$. For central 
West Bengal, the depth to the LGM surface ${ }^{22}$ is around $60 \mathrm{~m}$. Using our more relevant local field data, in this work we have assumed that the depth to the LGM surface is $70 \mathrm{mbgl}$. Our conclusions would not differ were we to set the LGM surface deeper at, say, $100 \mathrm{~m}$, because few of the wells we have sampled have depths between 70 and $100 \mathrm{~m}$ bgl depth.

S2. Geology of the Field Area. Reproduced below (Fig. S1) from Ref. 15 is a cross section through the field area from West to East. The line of section is line A-B of Fig. 1.

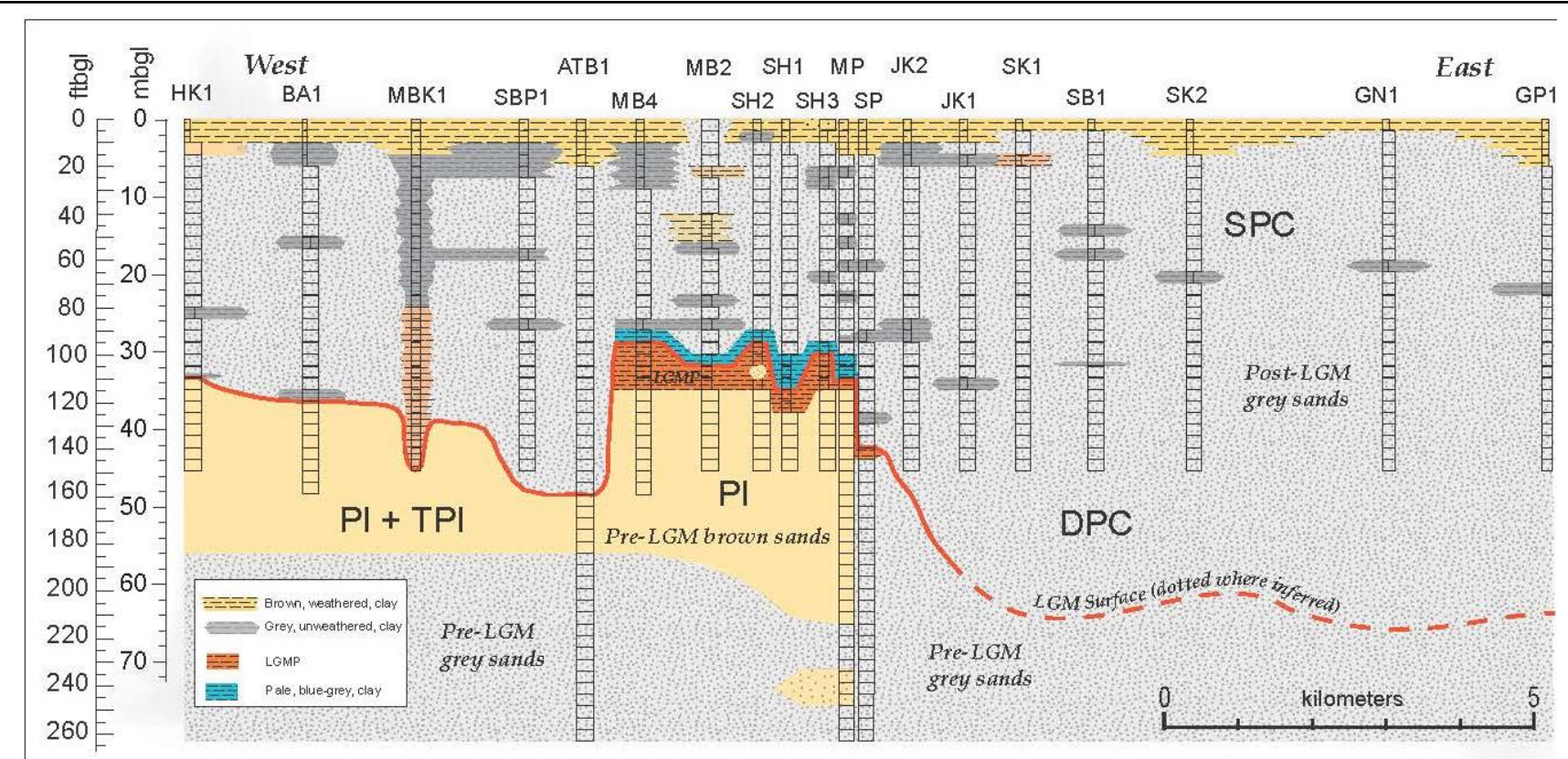

Fig. S1 Cross-section along line A-B in Fig. 1. LGMP = last glacial maximum palaeosol, which is overlain in some locations by a pale, blue-grey, clay. PI = palaeo-interfluve. $\mathrm{DPC}=$ deep palaeo-channel. $\mathrm{SPC}=$ shallow palaeo-channel. TPI = truncated palaeo-interfluve, where river incision since 6 ka has cut downwards and through the LGMP that caps the palaeo-interfluves.

The eastern two-thirds of the profile have been schematised in Fig. S2 in order to illustrate the hypothetical vulnerability of wells in Pleistocene aquifers to downward movement of As-pollution in overlying Holocene aquifers. Groundwaters in Pleistocene aquifers beneath deep palaeo-channels

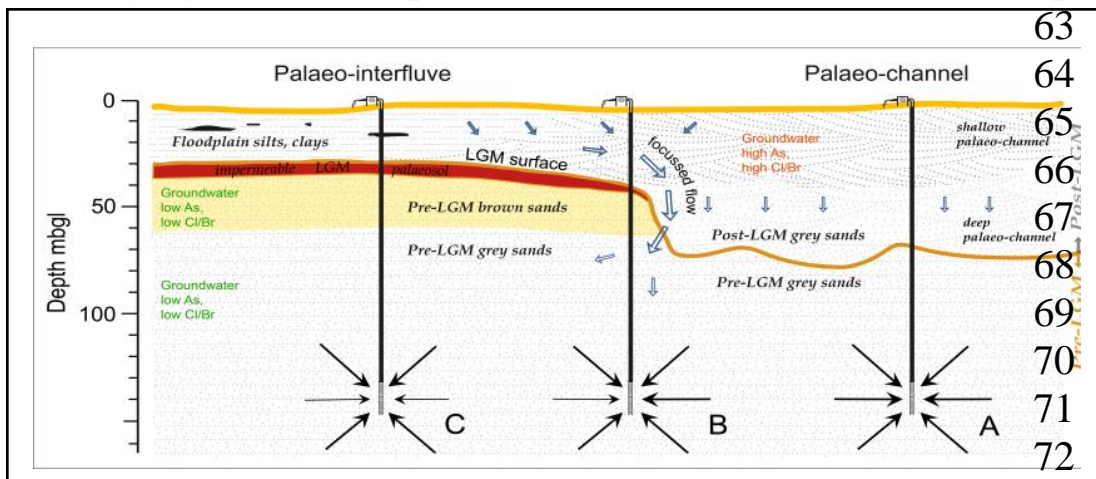

73

Fig. S2. Schematic cross-section of the solid part of the line of profile A7 $\$$ in Fig. 1 showing conceptualised command areas of wells in three settinqs: A, under a deep palaeo-channel. B, under a palaeo-interfluvial margin. under a palaeo-interfluvial interior. The well at B draws groundwater from beneath both palaeo-interfluves and deep palaeo-channels.
(Well A in Fig. S2) are more at risk of As-pollution from this source than are those beneath palaeo-interfluves (Well C in Fig. S2). The highest risk occurs at palaeo-interfluvial margins (Well B in Fig. S2) where downward flow is focused because most recharge to palaeo-interfluvial aquifers derives from adjacent aquifers, a lesser amount deriving from upflow beneath the palaeointerfluves.

S3. Analytical Methods. Samples from wells and piezometers were taken after purging into two $15 \mathrm{ml}$ polythene tubes, one acidified in the field with $0.15 \mathrm{ml}$ of $50 \%$ 
Analar ${ }^{\circledR}$ nitric acid for cation analysis, one unacidified for anion analysis. Samples were filtered using 0.45 micron membrane filters only when visibly turbid because we, and others ${ }^{23}$, have found that filtered and unfiltered analysis is indistinguishable unless turbid, and because we wished to measure the As concentration in water consumed, which is not filtered after being drawn. Chemical analysis was by ion chromatography for $\mathrm{Cl}$ and $\mathrm{SO}_{4}$ and ICP-MS for As and $\mathrm{Br}$ on acidified samples. For ICPMS, standards were matrix matched to an average groundwater composition for groundwater from West Bengal. Bromide standards were used and mass 79 measured. Backgrounds were high but very stable at around 2,000 cps from peak-spread on the Ar dimer at mass 80, enabling an RSD of $\leq 10 \%$ RSD down to $10 \mu \mathrm{g} / \mathrm{L} \mathrm{Br}$, and $\pm 1 \mu \mathrm{g} / \mathrm{L} \mathrm{Br}$ below that concentration. Sensitivity was around 500 $\mathrm{cps} / \mu \mathrm{g} / \mathrm{L} \mathrm{Br}$; the detection limit was around $1 \mu \mathrm{g} / \mathrm{L} \mathrm{Br}$. Analysis of oxygen and hydrogen stable isotopes were done on unacidified samples, filtered through $0.22 \mu \mathrm{m}$ membrane filters, using a Picarro WSCRDS laser instrument calibrated against standards USGS 46 and 48, with USGS 47 run as a sample to provide a further check on data quality. Analytical precision was $\pm 0.13 \%$ for $\delta^{18} \mathrm{O}$ and \pm 0.45 for $\delta^{2} \mathrm{H}$ (2s.d.).

\section{S4. Composition of Groundwaters from Well-Nests SP and MP}

Our interpretation is that As in deep groundwaters in Pleistocene aquifers has not been drawn down from shallow aquifers, even at palaeo-interfluvial margins. This contention receives support from the vertical distribution of $\mathrm{As}, \mathrm{Cl}$, and $\mathrm{Cl} / \mathrm{Br}$ in two piezometers, MP and SP, located within the

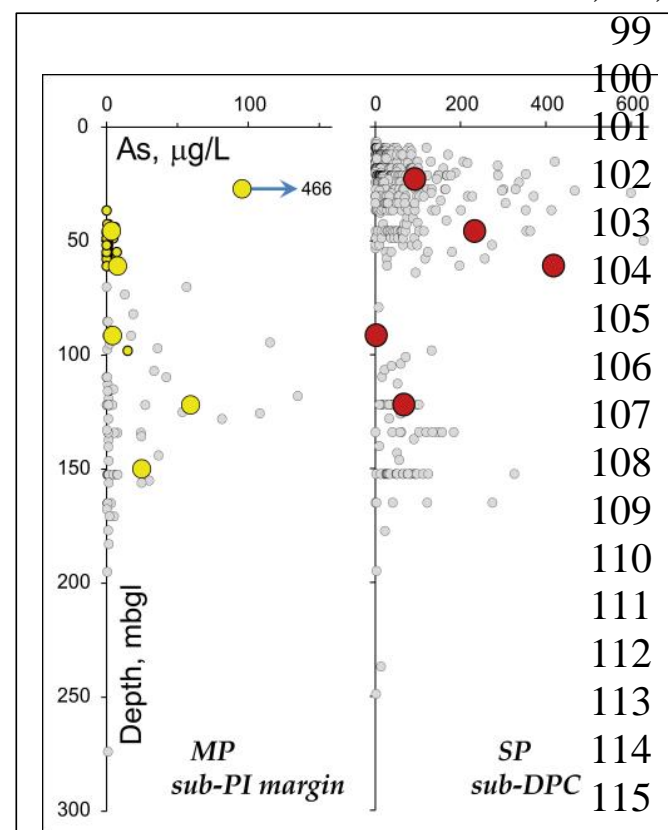

Fig. S3. Depth profile of As in piezometers $\mathrm{SP}$, at a palaeo-interfluvial margin, and MP, located $120 \mathrm{~m}$ to the west of SP towards the palaeo-interfluvial interior. Small grey symbols represent other wells sampled in this study.

site SP is natural and essentially in-situ. We postulate that the As at depth at site MP has been drawn-in laterally under the palaeointerfluvial margin by pumping and derives largely from the Pleistocene aquifer underlying the adjacent deep palaeo-channel aquifer, with no contribution from shallow levels and a minimal contribution from the adjacent deep palaeo-channel. A cross-plot of compositions of groundwater from $122 \mathrm{mbgl}$ field area (Fig. 1). The well-nest SP is located at the edge of a palaeo-channel: two boreholes $10 \mathrm{~m}$ apart revealed thin LGMP in the western-most and only grey sand (no LGMP) in the eastern-most. The well-nest MP is $120 \mathrm{~m}$ westward of SP in the direction of the interior of the palaeo-interfluve.

The vertical distribution of As at MP and SP (Fig. S3) show high As at shallow depth that is typical of Aspolluted shallow palaeo-channel groundwater. At and below 90 metres depth, $\mathrm{Cl}$ concentrations do not exceed $4 \mathrm{mg} / \mathrm{L}$ and groundwater $\mathrm{Cl} / \mathrm{Br}$ is on or below the brackish mixingline of Fig. 3, showing that at these depths, no shallow groundwater is present. Concentrations of As in both piezometers show a minimum at $90 \mathrm{~m}$ depth and are higher at deeper levels, a depth distribution also seen in the groundwaters (Fig. 2). This deep As is present in both MP and SP, albeit in concentrations of $<70 \mu \mathrm{g} / \mathrm{L}$ at depth. We interpret these profiles as showing that the As at depth at

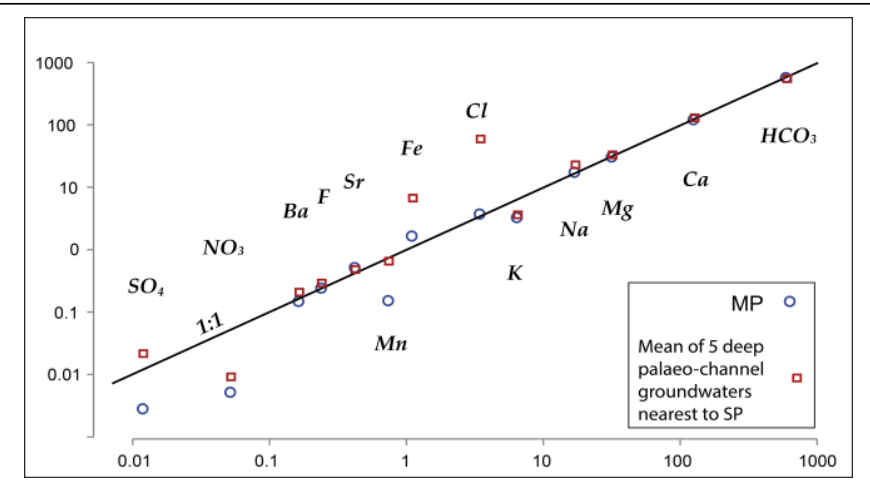

Fig. S4. Compositions of groundwaters at $122 \mathrm{mbgl}$ from piezometer SP compared top that from $122 \mathrm{mbgl}$ from MP and from deep palaeo-channels (35-70 mbgl) nearest to SP. In $\mathrm{SP}$, concentrations of $\mathrm{Cl}$ and $\mathrm{Fe}$ are close to those in MP but different from those in nearby palaeo-channel groundwaters. 
at sites SP and MP show a high degree of concordance (Fig. S4), especially for the more conservative species, supporting the hypothesis of mostly horizontal migration. The concentrations of As at depth differs little between the sites. The uppermost $30 \mathrm{~m}$ of the sediments comprising the palaeo-interfluvial aquifers consists of brown sand that can sorb $\mathrm{As}^{24,25}$. At greater depths, the sand is not oxidised, is grey, and presumably contains less iron-oxyhydroxide than the brown sands. Such grey sands will retard As migration less, and possibly hardly at all.

S5. Downward Piston Flow. Drawdown occurs to replace groundwater pumped for domestic supply and irrigation. To combat As-pollution in shallow aquifers, the government of West Bengal installed at least one deep community well per village to a depth of $152 \mathrm{~m}$ (500 feet bgl), the abstraction from which is $<10 \%$ of irrigation abstraction. To develop irrigation, from the early 1960's the Government of West Bengal installed numerous high-capacity deep wells for irrigation. These typically are of a total depth between 152 and $190 \mathrm{mbgl}$, with $176 \mathrm{~m}$ being a common depth. Screens are long, typically $30 \mathrm{~m}$. Each well typically supplies around $0.4 \mathrm{~km}^{2}$ of Boro (winter) rice with irrigation water during the dry season (February to May) across $74 \%$ of Nadia District and $67 \%$ of North 24 Paraganas District. There are no regulations that are effective in restricting well-spacing.

The total depth of flooding by irrigation pumping each year is typically $1 \mathrm{~m}$; we assume that $50 \%$ infiltrates and 50\% evaporates. Coupled to an aquifer porosity of $40 \%$ for unconsolidated sands, these figures equate to total piston-flow drawdown that has penetrated no more than $70 \mathrm{~m}$ across Nadia and South 24 Parganas since 1960.

Many factors influence such estimates. Estimates of drawdown will be lessened because not all deep wells are operational at any one time; many farmers prefer to use their own motorised shallow irrigation wells, which pull water from shallower depths; flood irrigation from high-capacity government wells is not applied uniformly, being used only for low ground where hydraulic gradients allow gravity flow to feed fields. Both high-yield irrigation wells and municipal high-yield supply wells have long screens, typically up to $30 \mathrm{~m}$, and the flow of water at any point through the screen will be inversely proportional to its distance from the pump intake: most pumped water comes from the screen area close to the pump intake and little originates from the lowest part of the screen. Drawdown of groundwater in marginal regions of the palaeo-interfluves may be underestimated because recharge to aquifers beneath palaeo-interfluves is focused at such margins.

Migration of groundwater and As from depth to beneath the palaeo-interfluvial aquifer must be occurring in response to extraction from beneath the impermeable LGMP. Drilling shows that the base of the brown sand in the vicinity of the piezometers is at a depth of about $70 \mathrm{mbgl}^{15}$, so it is important to note that the deep As has not passed through brown sands beneath the local palaeo-interfluve but has migrated through the underlying grey, pre-LGM, sands. We know of no data that quantifies sorption of As to pre-LGM grey sands, but speculate that such sands sorb less than do brown, palaeo-interfluvial sands, which are known to retard migration of dissolved As in the subsurface of the Bengal Basin ${ }^{24-25}$. 
S6. Cl mixing-models. A few groundwaters from Pleistocene aquifers beneath deep palaeochannels, and a few in Pleistocene aquifers beneath palaeo-interfluvial margins, fall above the $\mathrm{Cl} \mathrm{v}$ $\mathrm{Cl} / \mathrm{Br}$ mixing line for brackish water, are contaminated by shallow $\mathrm{Cl}$, and so might be polluted by shallow As. The proportion of contaminant shallow groundwater, derived from a Cl-based mixing model, ranges from $1.4 \%$ and $27 \%$ for the affected groundwaters from beneath palaeo-channels, and from $2.3 \%$ to $17 \%$ for the affected groundwaters from beneath palaeo-interfluvial margins. The As concentrations in groundwater in deep palaeo-channels (35 - $70 \mathrm{mbgl})$ ranges up to $640 \mu \mathrm{g} / \mathrm{L}$, but $75 \%$ of concentrations are $<100 \mu \mathrm{g} / \mathrm{L}^{15}$. Groundwater flow homogenises contaminant concentrations through hydrodynamic dispersion, so concentrations in any deep palaeo-channel groundwaters that moves downward would likely tend toward the mean or median concentrations, which are, respectively, 60 and $27 \mu \mathrm{g} / \mathrm{L}$ $(n=75$; Ref. 15). The maximum concentration of As that groundwater in deep palaeo-channels could supply to groundwaters beneath them would thus be $16 \mu \mathrm{g} / \mathrm{L}$ of As, and for most of the samples discussed would be a good deal less. With groundwaters beneath deep palaeochannels containing up to $326 \mu \mathrm{g} / \mathrm{L}$ As, but mostly concentrations in the range 10 to $100 \mu \mathrm{g} / \mathrm{L}$, the contribution to deep As from shallow groundwater is likely to be insignificant even in wells with elevated $\mathrm{Cl} / \mathrm{Br}$. Even in cases where shallow, high $\mathrm{Cl}$, high $\mathrm{Cl} / \mathrm{Br}$, groundwater might migrate to depth, its high content of $\mathrm{NO}_{3}$ and $\mathrm{SO}_{4}$ is likely to suppress Aspollution ${ }^{26}$ by preferential utilisation of $\mathrm{NO}_{3}$ for oxidation of DOC, and by sequestration of As in neoformed pyrite from sulphate reduction.

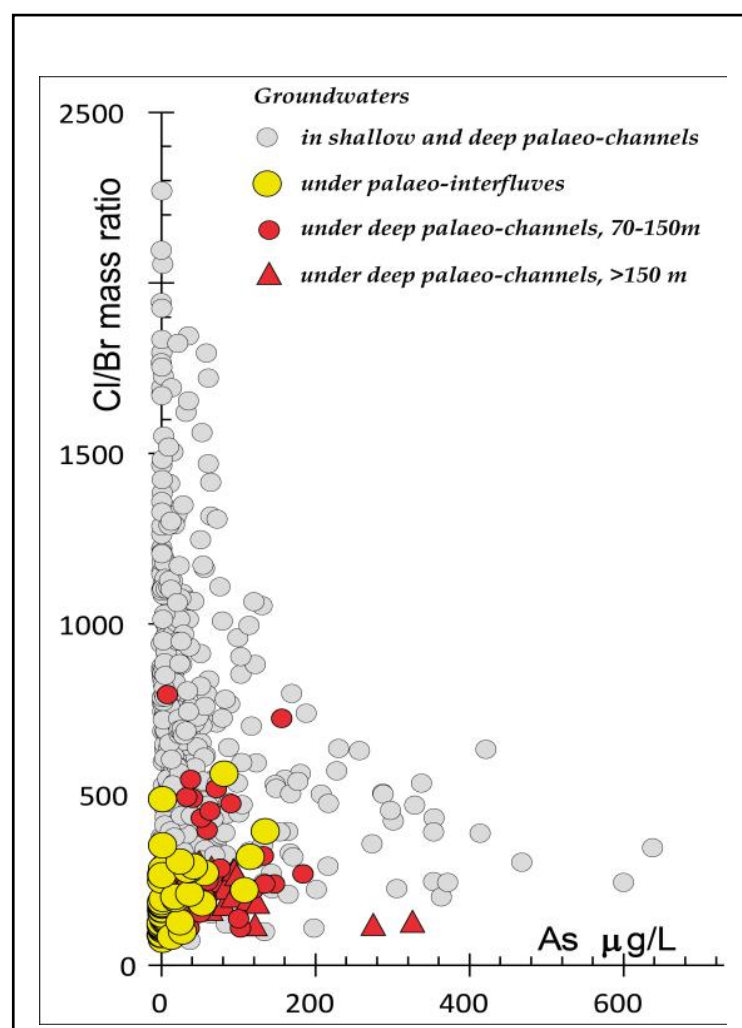

Fig. S5. Relation of As concentrations to $\mathrm{Cl} / \mathrm{Br}$ mass ratio. The inverse relationship arises through the addition to groundwater of waste water containing high concentrations of $\mathrm{Cl}$ and $\mathrm{NO}_{3}$. The $\mathrm{NO}_{3}$ suppresses reduction of $\mathrm{FeOOH}$ and so prevents reductive dissolution releasing As to groundwater. Data for groundwaters at depths $<70 \mathrm{~m}$ from Ref. 15. 
196

197

198

199

200

201

202

203

204

205

206

207

208

209

210

211

212

213

214

215

216

217

218

219

220

221

222

223

224

225

226

227

228

229

230

231

232

233

234

235

236

237

238

239

240

241

242

243

244

245

246

247

S7.

Fig. 6. Photos of Cores

The photos below are a representative selection showing the frequency and nature of clayey lenses in shallow and deep palaeo-channel sediments. For locations, see Ref 15.
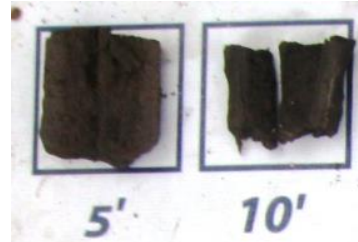

$10^{\prime}$
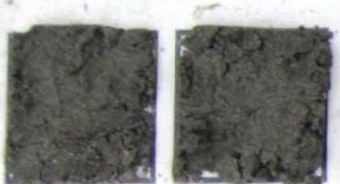

$55^{\prime} \quad 60^{\prime}$

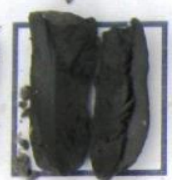

$65^{\prime}$

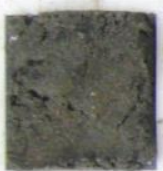

$105^{\prime}$
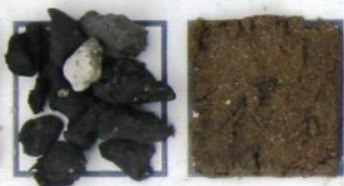

$115^{\prime}$
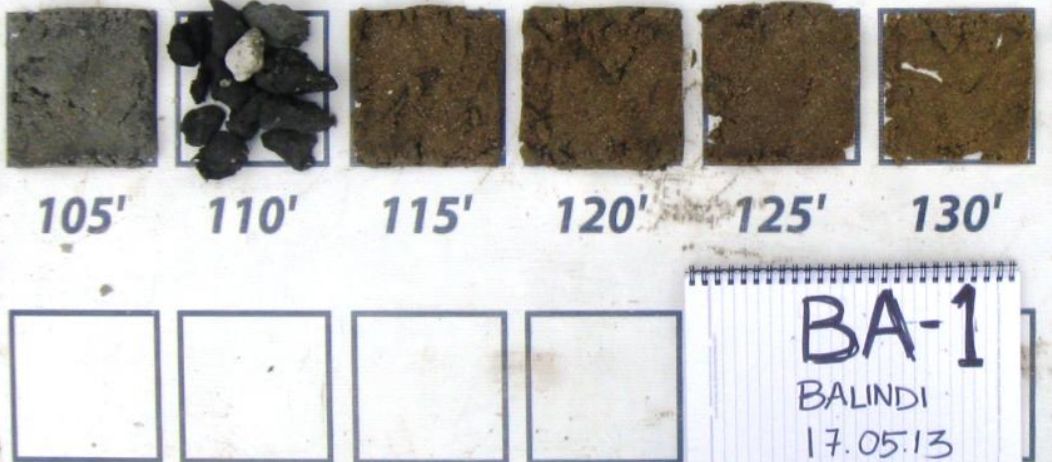

$130^{\prime}$

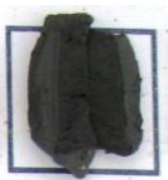

$35^{\prime}$

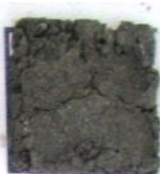

$40^{\prime}$

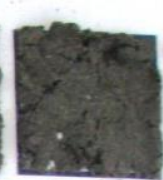

$45^{\prime}$

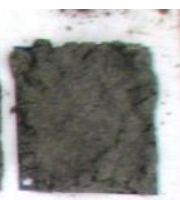

$50^{\prime}$
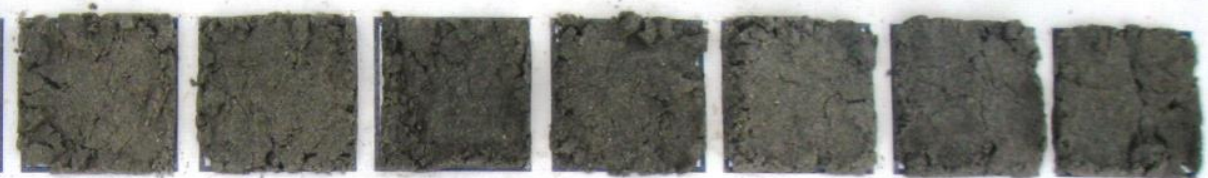

$120^{\prime} 125^{\prime}$

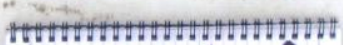
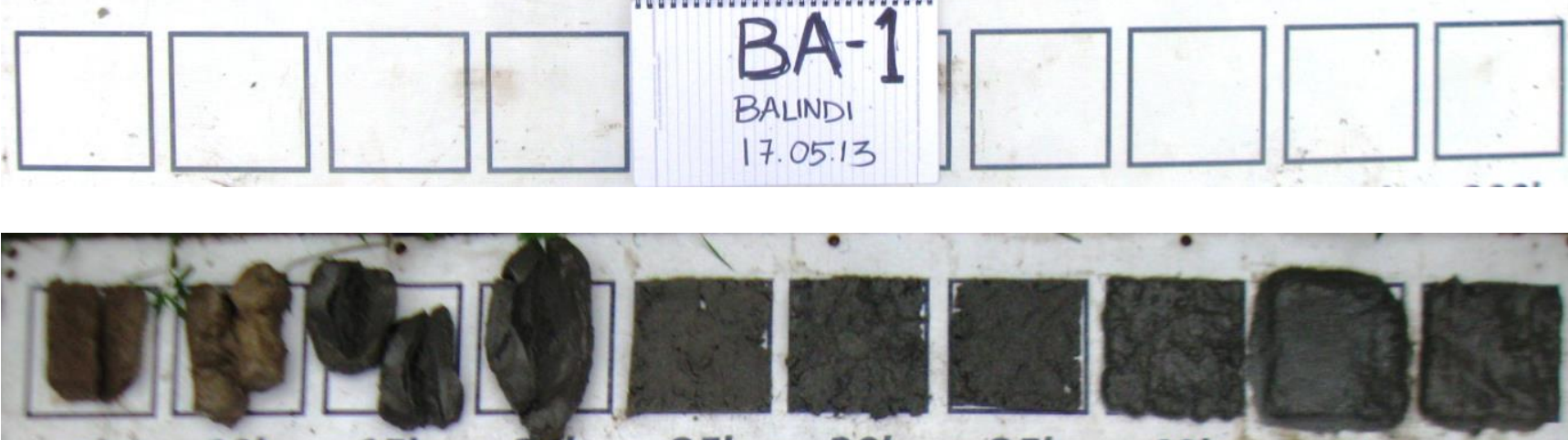

25' $30^{\prime}$

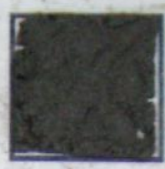

$35^{\prime}$
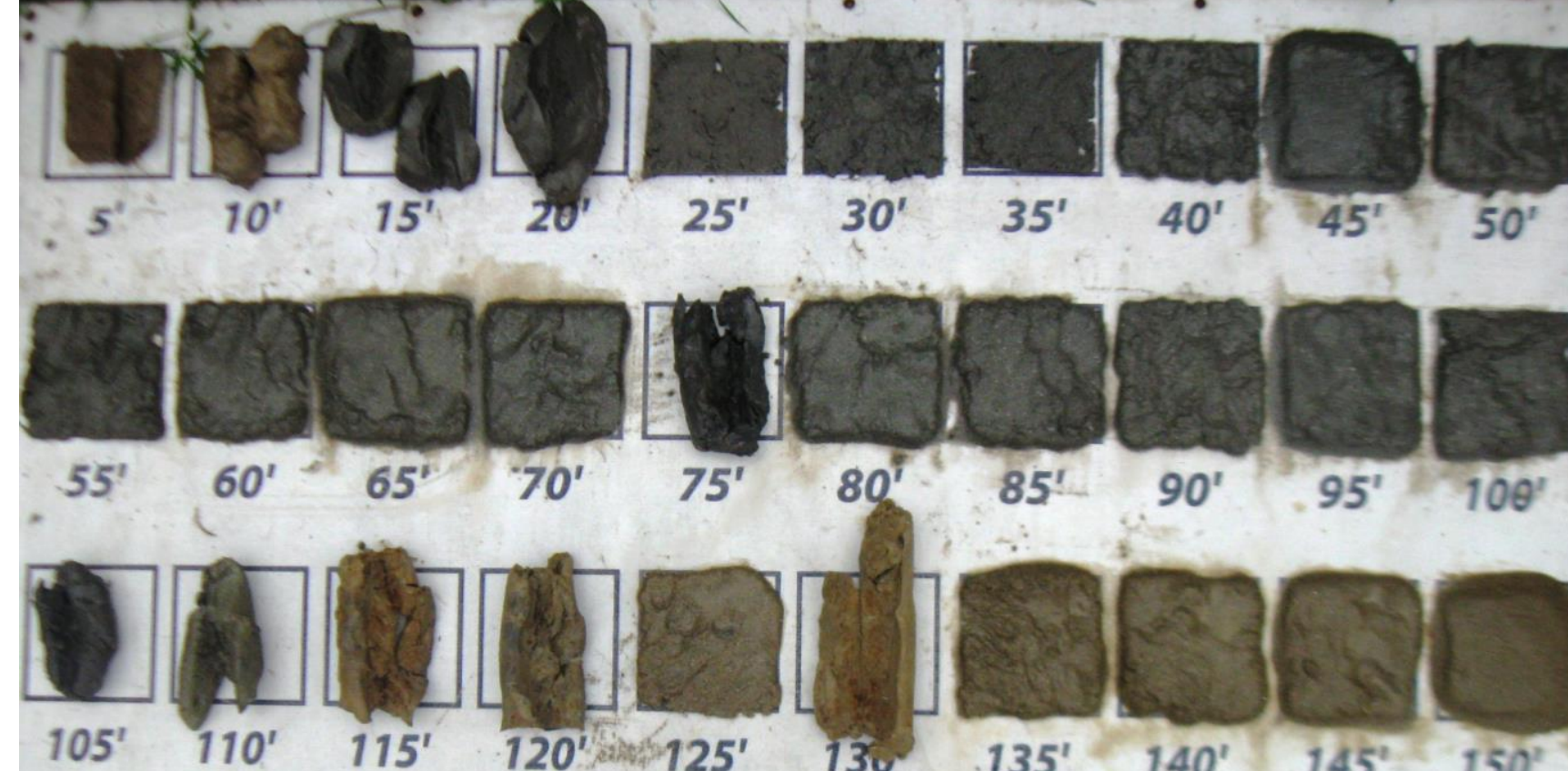

$105^{\prime} \quad 110^{\prime} \quad 115^{\prime}$

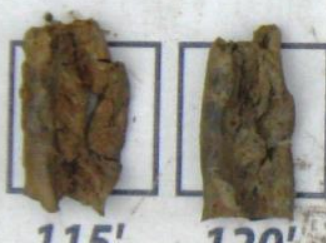

$75^{\prime}$
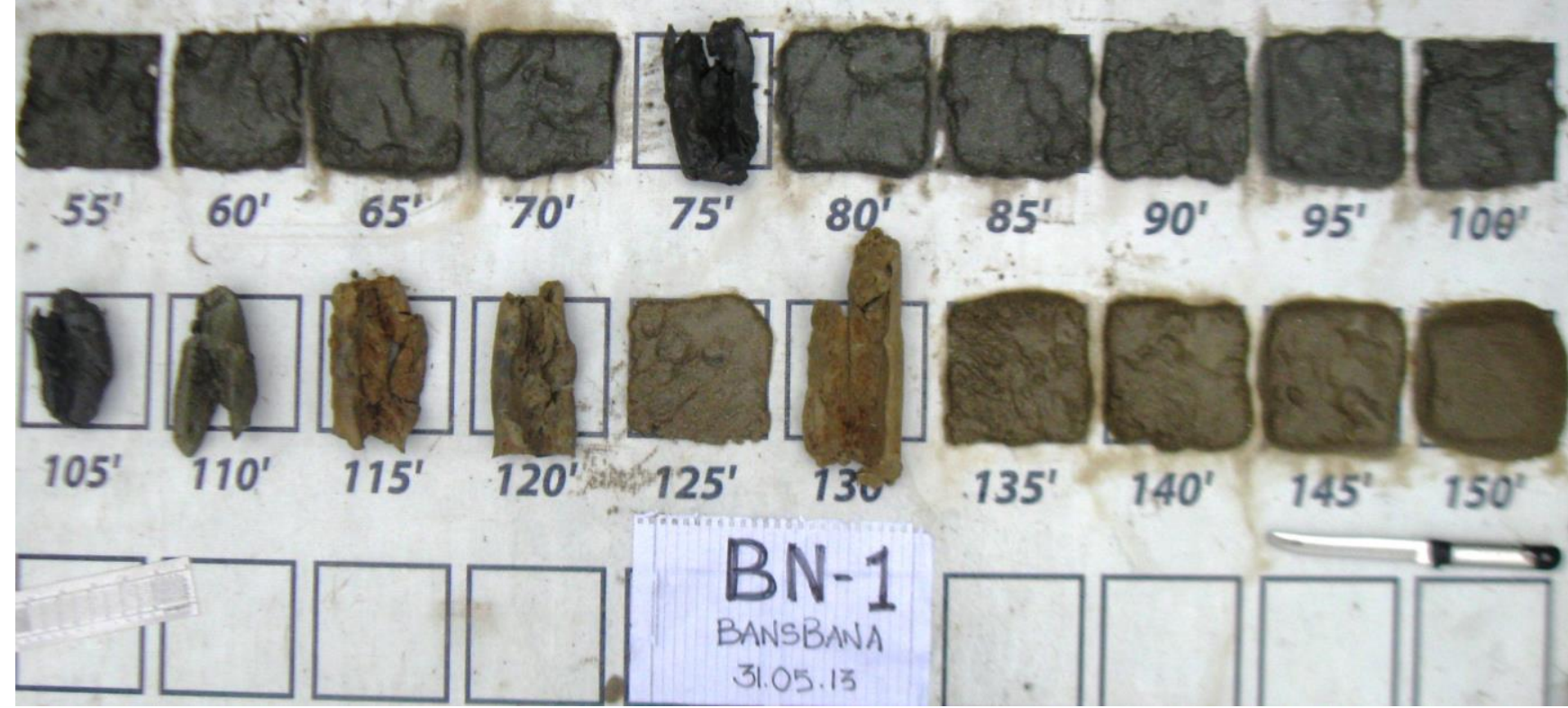

$120^{\prime} 125^{\prime}$

$135^{\prime}$

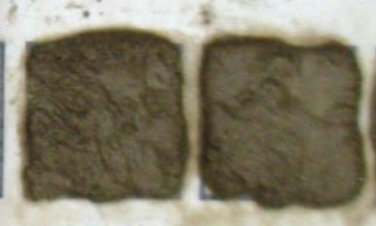

130

$140^{\prime}$

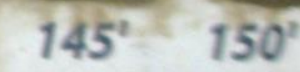


248

249

250

251

252

253

254

255

256

257

258

259

260

261

262

263

264

265

266

267

268

269

270

271

272

273

274

275

276

277

278

279

280

281

282

283

284

285

286

287

288

289

290

291

292

293

294

295

296
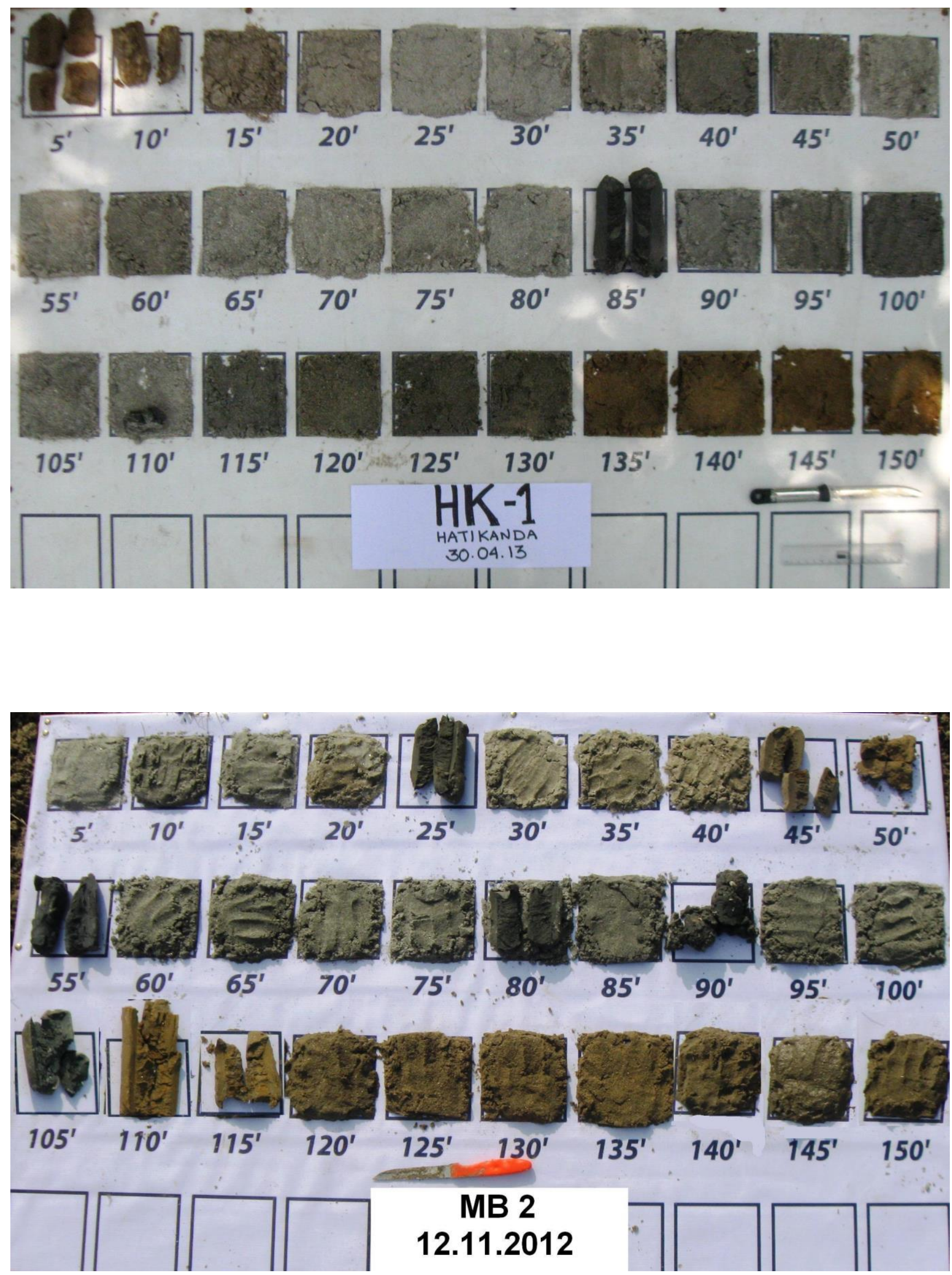
300

301

302

303

304

305

306

307

308

309

310

311

312

313

314

315

316

317

318

319

320

321

322

323

324

325

326

327

328

329

330

331

332

333

334

335

336

337

338

339

340

341

342

343

344

345

346

347

348

349

350

351
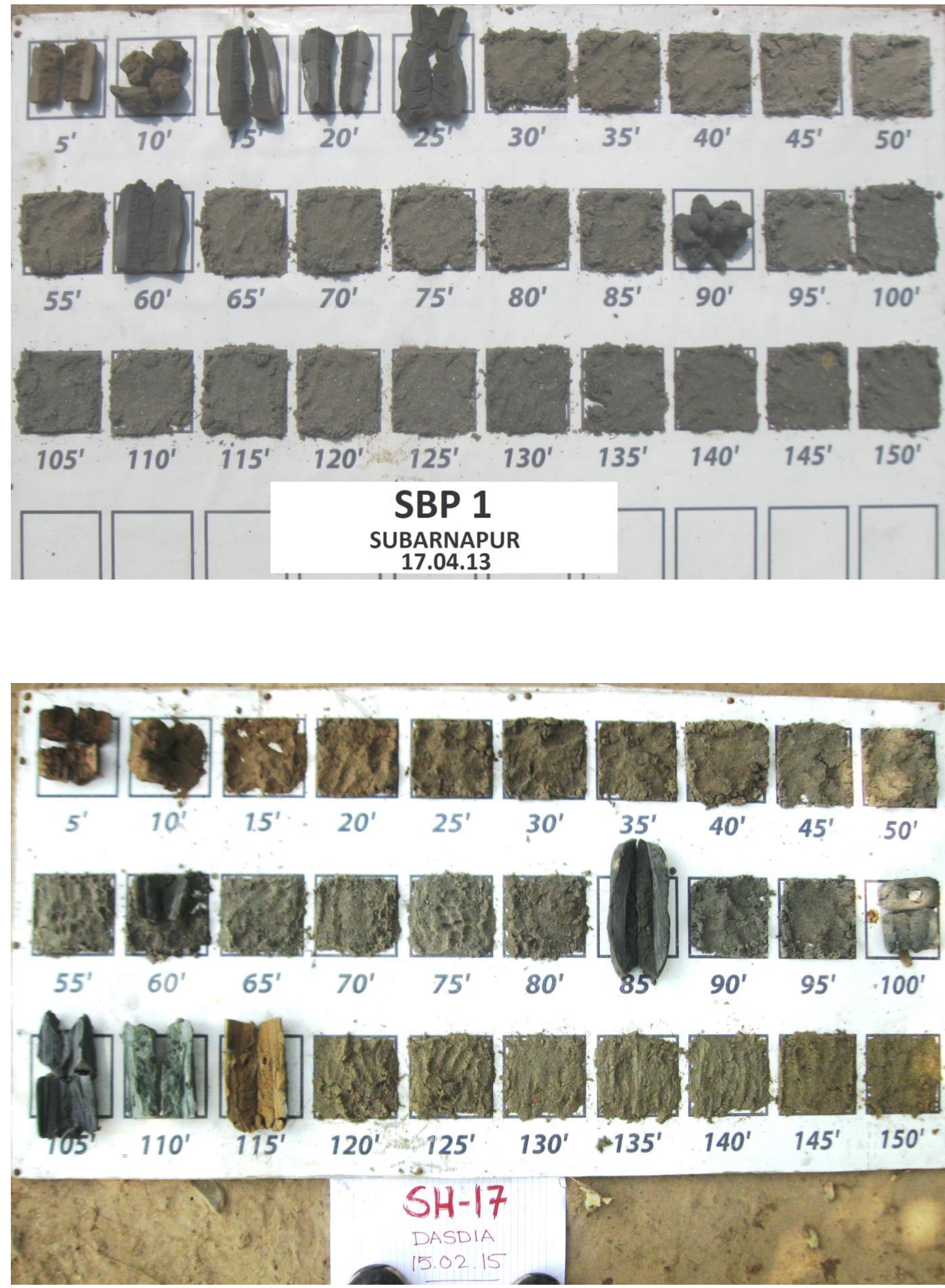


\section{References}

(1) Umitsu, M. Late Quaternary sedimentary environments and landforms in the Ganges Delta. Sed. Geol. 1993, 83, 177-186.

(2) DPHE 1999. Groundwater studies for Arsenic contamination in Bangladesh. Phase I: Rapid Investigation., Department of Public Health Engineering (DPHE) of Government of Bangladesh, British Geological Survey (BGS) and Mott MacDonald Ltd (MML) UK.

(3) Goodbred, S. L.; Kuehl, S. A. The significance of large sediment supply, active tectonism, and eustasy of margin sequence development: Late Quaternary stratigraphy and evolution of the GangesBrahmaputra delta. Sed. Geol. 2000, 133, 227-248.

(4) Goodbred, S. L. Jr.; Kuehl, S. A. Enormous Ganges-Brahmaputra sediment supply, active tectonism, and eustasy on margin sequence development: Late Quaternary stratigraphy and evolution of the Ganges-Brahmaputra delta. Geology, 2000, 28, 1083-1086.

(5) Allison, M. A. Geologic framework and environmental status of the Ganges-Brahmaputra Delta. Jour. Coastal Res. 1998,14, 3, 826-836.

(6) Allison, M. A. Historical changes in the Ganges-Brahmaputra Delta Front. Jour. Coastal Res., 1997, 14, 1269-1275.

(7) Allison, M. A.; Khan, S. R.; Goodbred S. L.; Kuehl S. A. Stratigraphic evolution of the late Holocene Ganges-Brahmaputra lower delta plain. Sed. Geol. 2003, 155, 317-342

(8) Goodbred, S. L. Jr.; Kuehl, S.A.; Steckler, M. S.; Sarkar, M. H. Controls on facies distribution and stratigraphic preservation in the Ganges-Brahmaputra delta sequence. Sed. Geol. 2003,155, 301-316.

(9) Pickering, J. L.; Goodbred, S. L.; Reitz, M. D.; Hartzog, T.R.; Mondal, D. R.; Hossain, Md. S. Late Quaternary Sedimentary Record and Holocene Channel Avulsions of the Jamuna and Old Brahmaputra River Valleys in the Upper Bengal Delta Plain, Geomorph. 2014, 227, 123-136. doi:10.1016/j.geomorph.2013.09.021.

(10) Lambeck, K.; Esat T. M.; Potter, E.-K. Links between climate and sea levels for the past three million years. Nature, 2002, 419, 199-206.

(11) Wiedicke, M.; Kudrass, H.-R.; Hübscher, C. H. Oolitic beach barriers of the last Glacial sea-level lowstand at the outer Bengal shelf. Marine Geology, 1999, 157, 7-18.

(12) McArthur J.M.; Ravenscroft P.; Banerjee D.M.; Milsom J.; Hudson-Edwards K. A.; Sengupta S.; Bristow C.; Sarkar S.; Tonkin S.; Purohit R. How paleosols influence groundwater flow and arsenic pollution: A model from the Bengal Basin and its worldwide implication. Water Resour. Res., 2008, 44: W11411.

(13) Hoque M.A.; McArthur J.M.; Sikdar P.K. The palaeosol model of arsenic pollution of groundwater tested along a $32 \mathrm{~km}$ traverse across West Bengal, India. Sci. Total Environ., 2012, 431: 157-165.

(14) Hoque MA, McArthur JM and Sikdar PK. Sources of low-arsenic groundwater in the Bengal Basin: investigating the influence of the last glacial maximum palaeosol using a $115-\mathrm{km}$ traverse across Bangladesh. Hydrogeology Journal, 2014, DOI 10.1007/s10040-014-1139-8.

(15) Ghosal U., Sikdar P.K. and McArthur J.M.. Palaeosol control of arsenic pollution: the Bengal Basin in West Bengal, India. Groundwater, 2015, 53, 588-599. DOI: 10.1111/gwat.12251.

(16) Sarkar A.; Sengupta, S; McArthur, J. M.; Ravenscroft, P.; Bera, M. K.; Bhushan, R.; Samanta A.; and Agrawal S. Evolution of Ganges-Brahmaputra western delta plain: Clues from sedimentology and carbon isotopes. Quaternary Science Reviews, 2009, 28, 2564-2581.

(17) DPHE 2001. Arsenic contamination of groundwater in Bangladesh. Kinniburgh, D.G. and Smedley, P.L. (eds). Department of Public Health Engineering (DPHE) of Government of Bangladesh and British Geological Survey (BGS) Keyworth.

(18) McArthur, J. M.; Banerjee, D. M.; Hudson-Edwards, K,A.; Mishra, R.; Purohit, R.; Ravenscroft, P.; Cronin, A.; Howarth, R. J.; Chatterjee, A.; Talukder, T.; Lowry, D.; Houghton, S.; Chadha, D. 
K. Natural organic matter in sedimentary basins and its relation arsenic in anoxic ground water: the example of West Bengal and its worldwide implications. Appl. Geochem. 2004, 19,1255-1293.

(19) McArthur, J. M.; Sikdar, P. K.; Nath, B.; Grassineau, N.; Marshall, J. D.; Banerjee D. M. Sedimentological control on Mn, and other trace elements, in groundwater of the Bengal Delta. Environ. Sci. Technol. 2012, 46, 669-676.

(20) van Geen, A.; Cheng, Z.; Jia, Q.; Seddique, A. A.; Rahman, M. W.; Rahman, M. M.; Ahmed, K. Z. Monitoring 51 community wells in Araihazar, Bangladesh, for up to 5 years: implications for arsenic mitigation. J. Environ. Sci. Health Part A 2007, 42, 1729-1740.

(21) von Brömssen M.; Larsson S. H.; Bhattacharya P.; Hasan M. A.; Ahmed K. M.; Jakariya M.; Sikder M. M. A; Sracek O.; Bivén A.; Doušová B.; Patriarca C.; Thunvik R.; Jacks G. Geochemical characterisation of shallow aquifer sediments of Matlab Upazila, Southeastern Bangladesh - Implications for targeting low-As aquifers. Journal of Contaminant Hydrology, 2008, 99, 137-149.

(22) Mukherjee, A.; Fryar, A. E.; Scanlon, B. R.; Bhattacharya, P.; Bhattacharya, A. Elevated arsenic in deeper groundwater of the western Bengal Basin, India: extent and controls from regional to local scale. Appl. Geochem. 2011, 26, 600-613.

(23) Zheng, Y.; Stute, M.; van Geen, A.; Gavrieli, I.; Dhar, R.; Simpson, H. J.; Schlosser, P.; Ahmed, K. M. Redox control of arsenic mobilization in Bangladesh groundwater. Appl. Geochem. 2004, 19, 201-214.

(24) Stollenwerk, K. G.; Breit, G. N.; Welch, A. H.; Yount, J. C.; Whitney, J. W.; Foster, A. L.; Uddin, M. N.; Majumder, R.K.; Ahmed, N. Arsenic attenuation by oxidized aquifer sediments in Bangladesh. Sci. Tot. Environ. 2007, 379, 133-150.

(25) Radloff, K. A.; Zheng, Y.; Michael, H. A.; Stute, M.; Bostick, B. C.; Mihajlov, I.; Bounds, M.; Huq M. R.; Choudhury I.; Rahman M.W.; Schlosser P.; Ahmed K. M.; van Geen A. Arsenic migration to deep groundwater in Bangladesh influenced by adsorption and water demand. Nat. Geosci. 2011, 4,793-8.

(26) McArthur J. M.; Sikdar P. K.; Hoque M. A.; Ghosal U. Waste-water impacts on groundwater: $\mathrm{Cl} / \mathrm{Br}$ ratios and implications for arsenic pollution of groundwater in the Bengal Basin. Sci. Total Environ. 2012, 437, 390-402. 
Table S1. Locations, depths, and composition of well waters.

Depths with an asterix were measured after removal of the pump.

$\begin{array}{llllr}\text { Sample } & \text { Long } & \text { Lat } & \text { Depth } & \text { Type } \\ \text { No } & \text { WGS84 } & \text { WGS84 } & \text { mbgl } & \text { of Well }\end{array}$

Piezo at SP

$\begin{array}{lrrrr}\text { WB11DS09 65 } & 88.605 & 22.959 & 23 & \text { ordinary } \\ \text { WB11DS12 SP1 } & 88.605 & 22.959 & 46 & \text { Piezometer } \\ \text { WB11DS12 SP2 } & 88.605 & 22.959 & 61 & \text { Piezometer } \\ \text { WB11DS12 SP3 } & 88.605 & 22.959 & 91 & \text { Piezometer } \\ \text { WB11DS12 SP4 } & 88.605 & 22.959 & 122 & \text { Piezometer }\end{array}$

Piezo at MP

$\begin{array}{lllrr}\text { WB11DS12 MP1 } & 88.603 & 22.959 & 29 & \text { Piezometer } \\ \text { WB11DS12 MP2 } & 88.603 & 22.959 & 46 & \text { Piezometer } \\ \text { WB11DS12 MP3 } & 88.603 & 22.959 & 61 & \text { Piezometer } \\ \text { WB11DS12 MP4 } & 88.603 & 22.959 & 91 & \text { Piezometer } \\ \text { WB11DS08 61 } & 88.604 & 22.959 & 122 & \text { Mark II } \\ \text { WB12DS07 62A } & 88.603 & 22.959 & 150 & \text { Swajaldhara }\end{array}$

$\begin{array}{rrrrrrr} & \delta 180 & \delta \mathrm{D} & \mathrm{Cl} & \mathrm{SO}_{4} & \mathrm{As} & \mathrm{Br} \\ \text { Area } & \% & \% & \mathrm{ppm} & \mathrm{ppm} & \mathrm{ppb} & \mathrm{ppb}\end{array}$

$\begin{array}{lrrrrrr}\text { Nonaghata } & -1.4 & -15.0 & 42.4 & 0.01 & 466 & 61 \\ \text { Nonaghata } & -4.9 & -29.0 & 2.5 & 0.03 & 4 & 19 \\ \text { Nonaghata } & -4.8 & -30.8 & 2.5 & 0.02 & 8 & 17 \\ \text { Nonaghata } & -4.9 & -31.6 & 2.1 & 0.00 & 4 & 16 \\ \text { Nonaghata } & -4.4 & -30.0 & 3.7 & 0.00 & 59 & 20 \\ \text { Nonaghata } & -4.5 & -29.8 & 4.0 & 0.00 & 25 & 22\end{array}$

Pleistocene Aquifers $>70$ depth under a Palaeo-interfluve

\begin{tabular}{|c|c|c|c|c|}
\hline UG13 PN 3 & 88.586 & 22.994 & 70 & HTW \\
\hline FTP 6 & 88.583 & 22.941 & 76 & HTW \\
\hline UG12 FP 91 & 88.592 & 22.944 & 85 & HTW \\
\hline UG13 MUR 9 & 88.547 & 22.972 & 85 & HTW \\
\hline WB12 DS06 181 & 88.589 & 22.950 & 91 & HTW \\
\hline NG 2 & 88.567 & 23.032 & 95 & DIW \\
\hline UG13 BN 8 & 88.583 & 22.924 & 98 & HTW \\
\hline WB12 DS06 201 & 88.597 & 22.961 & 110 & HTW \\
\hline UG13 SIM 2 & 88.520 & 23.024 & 110 & Mark II \\
\hline Mura 1 & 88.537 & 22.973 & 113 & \\
\hline BIS 2 & 88.568 & 23.011 & 115 & Mark II \\
\hline UG13 BA 2 & 88.533 & 22.969 & 116 & HTW \\
\hline WB11DS12 92 & 88.596 & 22.958 & 116 & HTW \\
\hline UG13 MBK 2 & 88.554 & 22.946 & 116 & HTW \\
\hline KRB 1 & 88.584 & 22.966 & 122 & \\
\hline WB11DS08 48A & 88.594 & 22.952 & 122 & HTW \\
\hline UG13 PN 14 & 88.595 & 22.989 & 122 & HTW \\
\hline UG13 GTR 1 & 88.583 & 23.020 & 122 & HTW \\
\hline WB11DS08 8 & 88.604 & 22.958 & 122 & HTW \\
\hline UG13 MBK 1 & 88.546 & 22.947 & 122 & HTW \\
\hline UG13 BA 1 & 88.533 & 22.969 & 122 & HTW \\
\hline RTN 2 & 88.566 & 22.895 & 122 & HPW \\
\hline
\end{tabular}

\begin{tabular}{|c|c|c|c|c|c|c|}
\hline Panpur & & & 2.1 & 0.14 & 0 & 24 \\
\hline Majherpara, Fatehpur & & & 2.6 & 0.00 & 0 & 17 \\
\hline Fatehpur & & & 2.4 & 0.01 & 0 & 14 \\
\hline Muragacha & -4.2 & -27.2 & 3.3 & 0.00 & 1 & 19 \\
\hline Ghulam ali para_dasdia & -5.2 & -33.2 & 2.0 & 0.05 & 0 & 12 \\
\hline & & & 5.4 & 0.01 & 2 & 28 \\
\hline Bansbana & -4.7 & -30.0 & 3.5 & 0.00 & 1 & 19 \\
\hline Daspara_Dasdia & -5.3 & -33.9 & 1.4 & 0.06 & 0 & 12 \\
\hline Simurali & & & 9.3 & 17.82 & 1 & 37 \\
\hline Muragacha & & & 11.3 & 0.05 & 1 & 110 \\
\hline Bizra & -4.0 & -26.6 & 4.9 & 0.00 & 5 & 36 \\
\hline Balindi & -3.5 & -23.4 & 3.9 & 0.03 & 1 & 24 \\
\hline Daspara & -4.9 & -33.8 & 1.3 & 0.00 & 1 & 12 \\
\hline Mobarekpur & -4.5 & -28.1 & 4.2 & 0.00 & 2 & 40 \\
\hline Kurambelia & & & 2.9 & 0.00 & 0 & 25 \\
\hline Ghulam Ali para & -4.2 & -26.1 & 22.5 & 0.01 & 1 & 85 \\
\hline Panpur & -4.2 & -30.5 & 3.4 & 0.04 & 1 & 38 \\
\hline Gotera & -3.9 & -27.2 & 11.0 & 0.05 & 1 & 68 \\
\hline Nonaghata & -3.8 & -24.3 & 385 & 0.05 & 2 & 1361 \\
\hline Jaguli & -4.2 & -26.6 & 6.7 & 0.00 & 3 & 51 \\
\hline Balindi & & & 5.1 & 0.00 & 4 & 37 \\
\hline Ruitanpur & -4.6 & -30.6 & 2.6 & 0.00 & 2 & 22 \\
\hline
\end{tabular}




\begin{tabular}{|c|c|c|c|c|c|c|c|c|c|c|}
\hline SMH 2 & 88.549 & 22.954 & 122 & HPW & Simhat Primary School & -4.0 & -26.6 & 5.0 & 0.00 & 2 \\
\hline PNP & 88.579 & 22.996 & 128 & DIW & Panpur & -4.5 & -30.1 & 4.0 & 0.02 & 1 \\
\hline FTP 2 & 88.592 & 22.929 & 130 & Mark II & Dakshin para, Fatehpur & & & 7.0 & 0.00 & 5 \\
\hline KRB 10 & 88.577 & 22.983 & 130 & Mark II & Nischintapur, Kurambelia & & & 2.9 & 0.00 & 3 \\
\hline UG13 PN 16 & 88.591 & 22.984 & 133 & HTW & Panpur & -5.3 & -34.6 & 2.8 & 0.23 & 0 \\
\hline UG13 PN 17 & 88.593 & 22.984 & 134 & HTW & Panpur & -4.7 & -30.4 & 6.0 & 0.00 & 1 \\
\hline UG13 BA 3 & 88.534 & 22.970 & 134 & HTW & Balindi & & & 4.7 & 0.00 & 5 \\
\hline Molla 3 & 88.585 & 22.950 & 134 & & Mollabelia & & & 1.6 & 0.00 & 7.7 \\
\hline MBL & 88.590 & 22.986 & 134 & DIW & Mullebelia & -4.8 & -32.9 & 2.6 & 0.20 & 1 \\
\hline NRP 2 & 88.521 & 23.024 & 137 & DIW & & -4.5 & -29.9 & 4.7 & 0.69 & 1 \\
\hline NRP 1 & 88.533 & 23.018 & 140 & DIW & & -4.5 & -30.0 & 6.4 & 0.09 & 1 \\
\hline JRP & 88.533 & 23.024 & 146 & DIW & & -5.0 & -32.2 & 2.7 & 0.67 & 2 \\
\hline WB12 DS06 184 & 88.589 & 22.950 & 152 & Mark II & & -5.3 & -33.3 & 1.4 & 0.06 & 1 \\
\hline UG13 PN 44 & 88.585 & 22.989 & 152 & Mark II & Panpur & -5.0 & -32.0 & 3.3 & 0.00 & 1 \\
\hline UG13 PN 15 & 88.589 & 22.987 & 152 & DIW & Panpur & -5.1 & -33.1 & 2.5 & 0.11 & 1 \\
\hline UG13 SIM 1 & 88.521 & 23.025 & 152 & Mark II & Simurali & & & 5.3 & 0.05 & 1 \\
\hline UG13 PN 53 & 88.577 & 22.998 & 152 & Mark II & Panpur & -5.1 & -31.5 & 4.2 & 0.00 & 1 \\
\hline WB12 DS06 182 & 88.589 & 22.950 & 152 & Mark II & & -5.2 & -32.7 & 2.4 & 0.05 & 2 \\
\hline UG 13 HKN 11 & 88.529 & 22.942 & 152 & Mark II & Hatikanda & -4.7 & -30.7 & 6.9 & 0.03 & 5 \\
\hline UG13 PN 52 & 88.581 & 22.993 & 152 & HTW & Panpur & -4.5 & -30.9 & 3.5 & 0.00 & 7 \\
\hline UG13 BA 10 & 88.533 & 22.968 & 152 & Mk II & Balindi & -4.2 & -27.7 & 4.7 & 0.03 & 8 \\
\hline UG12 FP 29 & 88.584 & 22.942 & 156 & Mark II & Fatehpur & & & 2.8 & 0.00 & 2 \\
\hline DIG 2 & 88.540 & 22.944 & 165 & Mark II & Digha, Harighata & -4.5 & -29.0 & 9.7 & 0.57 & 1 \\
\hline ANN & 88.544 & 22.927 & 165 & Mark II & Harighata & -3.5 & -20.9 & 69.6 & 14.04 & 1 \\
\hline FAT 1 & 88.583 & 22.945 & 165 & Mark II & Harighata & -3.6 & -22.0 & 34.6 & 4.92 & 3 \\
\hline FAT 2 & 88.584 & 22.945 & 165 & Mark II & Harighata & -3.6 & -22.0 & 44.9 & 3.99 & 3 \\
\hline DIG 1 & 88.543 & 22.943 & 165 & Mark II & Dhiga village & -4.3 & -27.9 & 5.4 & 0.01 & 1 \\
\hline UG13 PN 18 & 88.594 & 22.983 & 168 & Mark II & Panpur & -4.9 & -30.8 & 8.0 & 0.00 & 0 \\
\hline UG12 FP 72 & 88.592 & 22.929 & 171 & Mark II & Fatehpur & & & 7.0 & 0.00 & 5 \\
\hline $\mathrm{CHP}$ & 88.508 & 23.026 & 171 & DIW & & -4.9 & -31.8 & 3.1 & 1.38 & 2 \\
\hline NG 1 & 88.559 & 23.034 & 177 & DIW & & -4.5 & -29.9 & 6.2 & 0.09 & 1 \\
\hline RMP & 88.510 & 23.020 & 183 & DIW & & -4.8 & -32.0 & 2.6 & 0.68 & 2 \\
\hline UG12 FP 10 & 88.585 & 22.944 & 195 & Mark II & Fatehpur & & & 32.5 & 5.31 & 1 \\
\hline BIS 1 & 88.573 & 22.996 & 274 & DIW & Bizra & -4.8 & -31.7 & 2.6 & 0.00 & 1 \\
\hline
\end{tabular}

Pleistocene Aquifers at 35 - 70 mbgl under a Palaeo-interfluve

Others lacking stable isotope data can be found in Ghosal et al. 2015

$\begin{array}{lllll}\text { UG13 MBK 10 } & 88.549 & 22.945 & 43 & \text { HTW } \\ \text { UG13 MBK 12 } & 88.550 & 22.944 & 43 & \text { HTW } \\ \text { WB12 DS06 208 } & 88.603 & 22.958 & 46 & \text { HTW } \\ \text { WB11DS08 68 } & 88.604 & 22.960 & 46 & \text { HTW } \\ \text { UG13 PN 45 } & 88.583 & 22.992 & 46 & \text { HTW } \\ \text { UG13 PN 33 } & 88.586 & 22.987 & 46 & \text { HTW } \\ \text { UG13 MBK 11 } & 88.550 & 22.944 & 46 & \text { HTW } \\ \text { SMH 1 } & 88.546 & 22.954 & 46 & \text { HPW } \\ \text { BIS 4 } & 88.575 & 23.000 & 46 & \text { SIW } \\ \text { WB12 DS06 207 } & 88.603 & 22.958 & 49 & \text { HTW }\end{array}$

$\begin{array}{rrrrrrr}\text { Mobarekpur } & -4.0 & -27.7 & 14.6 & 1.65 & 2 & 92 \\ \text { Mobarekpur } & -2.1 & -16.6 & 5.1 & 0.02 & 1 & 45 \\ \text { Kuthipara_Dasdia } & -5.1 & -31.4 & 2.3 & 0.05 & 0 & 18 \\ \text { Nonaghata } & -5.0 & -31.1 & 2.4 & 0.00 & 1 & 16 \\ \text { Panpur } & -4.8 & -30.2 & 2.6 & 0.00 & 0 & 36 \\ \text { Panpur } & -4.5 & -27.6 & 2.1 & 0.00 & 0 & 16 \\ \text { Mobarekpur } & -2.2 & -17.2 & 6.7 & 0.50 & 1 & 32 \\ \text { Simhat } & -4.88 & 31.75 & 12.3 & 1.60 & 0 & 320 \\ \text { Bizra } & -4.50 & 30.63 & 2.5 & 0.09 & 1 & 29 \\ \text { Nonaghata } & -5.0 & -31.5 & 2.5 & 0.10 & 1 & 18\end{array}$




\begin{tabular}{lllll} 
WB12 DS06 206 & 88.603 & 22.957 & 49 & HTW \\
UG13 PN 42 & 88.589 & 22.993 & 49 & SIW \\
UG13 PN 20 & 88.596 & 22.991 & 49 & HTW \\
UG13 PN 23 & 88.595 & 22.991 & 49 & HTW \\
UG13 PN 24 & 88.595 & 22.990 & 49 & HTW \\
UG13 PN 22 & 88.596 & 22.991 & 49 & HTW \\
UG13 PN 21 & 88.595 & 22.991 & 49 & HTW \\
UG13 PN 27 & 88.595 & 22.989 & 50 & HTW \\
UG13 PN 50 & 88.584 & 22.991 & 52 & HTW \\
UG13 PN 25 & 88.595 & 22.990 & 52 & HTW \\
WB11DS12 60 & 88.597 & 22.956 & 55 & SIW \\
UG13 PN 31 & 88.594 & 22.988 & 55 & SIW \\
UG13 PN 28 & 88.595 & 22.989 & 55 & HTW \\
UG13 PN 43 & 88.589 & 22.995 & 55 & SIW \\
UG13 PN 26 & 88.595 & 22.990 & 56 & HTW \\
WB11DS12 165 & 88.592 & 22.953 & 58 & SIW \\
UG13 PN 47 & 88.583 & 22.991 & 61 & HTW \\
UG13 PN 46 & 88.583 & 22.991 & 61 & HTW \\
UG13 PN 48 & 88.583 & 22.991 & 61 & HTW \\
SAT & 88.581 & 23.012 & 61 & SIW \\
\hline
\end{tabular}

\begin{tabular}{|c|c|c|c|c|c|}
\hline Nonaghata & -4.8 & -30.0 & 3.2 & 0.10 & 0 \\
\hline Panpur & -4.5 & -29.4 & 3.1 & 0.01 & 2 \\
\hline Panpur & -4.2 & -27.1 & 4.4 & 0.00 & 5 \\
\hline Panpur & -4.2 & -27.8 & 4.7 & 0.00 & 0 \\
\hline Panpur & -4.2 & -28.1 & 4.3 & 0.01 & 1 \\
\hline Panpur & -4.1 & -27.3 & 4.1 & 0.00 & 0 \\
\hline Panpur & -3.9 & -27.0 & 4.1 & 0.00 & 0 \\
\hline Panpur & -4.4 & -29.6 & 2.8 & 0.04 & 1 \\
\hline Panpur & -4.7 & -28.9 & 3.3 & 0.02 & 0 \\
\hline Panpur & -4.3 & -28.6 & 5.1 & 0.00 & 0 \\
\hline Daspara & -5.1 & -33.8 & 1.8 & 0.33 & 0 \\
\hline Panpur & -4.4 & -29.2 & 2.1 & 0.01 & 0 \\
\hline Panpur & -4.4 & -29.9 & 3.0 & 0.00 & 0 \\
\hline Panpur & -3.8 & -26.2 & 4.3 & 0.00 & 7 \\
\hline Panpur & -4.0 & -28.4 & 3.8 & 0.00 & 0 \\
\hline Nonaghata & -5.0 & -33.4 & 1.9 & 0.02 & 1 \\
\hline Panpur & -4.7 & -30.6 & 2.5 & 0.00 & 1 \\
\hline Panpur & -4.7 & -29.5 & 3.2 & 0.01 & 1 \\
\hline Panpur & -4.4 & -27.1 & 3.1 & 0.00 & 0 \\
\hline arge paddy. & -3.67 & 25.39 & 6.2 & 0.00 & 1 \\
\hline
\end{tabular}

Pleistocene Aquifers at $>70 \mathrm{mbgl}$ under a Palaeo-interfluvial Margin

\begin{tabular}{|c|c|c|c|c|}
\hline WB11DS09 07 & 88.604 & 22.958 & 70 & HTW \\
\hline UG13 PN 13 & 88.594 & 22.988 & 73 & ${ }^{*} \mathrm{HTW}$ \\
\hline UG13 MBK 8 & 88.549 & 22.945 & 82 & ${ }^{*} \mathrm{HTW}$ \\
\hline UG12 FP 182 & 88.586 & 22.941 & 91 & HTW \\
\hline UG13 MBK 6 & 88.549 & 22.944 & 91 & HTW \\
\hline UG12 FP 92 & 88.592 & 22.944 & 94 & ${ }^{*} \mathrm{HTW}$ \\
\hline UG12 FP 169 & 88.588 & 22.939 & 97 & ${ }^{*}$ Mark II \\
\hline UG13 MBK 3 & 88.549 & 22.944 & 98 & ${ }^{*} \mathrm{HTW}$ \\
\hline UG12 FP 100 & 88.591 & 22.945 & 107 & ${ }^{*}$ Mark II \\
\hline BNB 4 & 88.583 & 22.931 & 110 & \\
\hline UG 13 HKN 9 & 88.517 & 22.937 & 116 & HTW \\
\hline UG13 BN 14 & 88.584 & 22.925 & 118 & ${ }^{*}$ Mark II \\
\hline UG13 BHA 9 & 88.548 & 22.927 & 119 & ${ }^{*}$ Mark II \\
\hline Fateh 3 & 88.592 & 22.945 & 122 & \\
\hline UG13 SBN 17 & 88.577 & 22.946 & 125 & Mark II \\
\hline UG12 FP 30 & 88.584 & 22.941 & 126 & ${ }^{*} \mathrm{HTW}$ \\
\hline UG13 SBN 15 & 88.573 & 22.956 & 128 & ${ }^{*}$ Mark II \\
\hline KRB 4 & 88.595 & 22.972 & 134 & \\
\hline UG13 PN 12 & 88.577 & 22.986 & 136 & ${ }^{*} \mathrm{HTW}$ \\
\hline UG13 SBN 16 & 88.580 & 22.956 & 144 & ${ }^{*} \mathrm{HTW}$ \\
\hline UG13 KM 1 & 88.594 & 22.974 & 155 & ${ }^{*}$ Mark II \\
\hline UG13 MBK 7 & 88.549 & 22.944 & 156 & ${ }^{*} \mathrm{HTW}$ \\
\hline
\end{tabular}

\begin{tabular}{|c|c|c|c|c|c|}
\hline Nonaghata & & & 8.3 & 0.00 & 56 \\
\hline Panpur & -4.5 & -29.8 & 2.5 & 0.03 & 13 \\
\hline Mobarekpur & -3.1 & -21.4 & 6.6 & 0.04 & 19 \\
\hline Fatehpur & & & 4.2 & 0.01 & 1 \\
\hline Mobarekpur & -3.6 & -24.8 & 6.2 & 0.00 & 17 \\
\hline Fatehpur & & & 6.1 & 0.00 & 115 \\
\hline Fatehpur & & & 4.2 & 0.00 & 36 \\
\hline Mobarekpur & -2.9 & -20.9 & 6.8 & 0.00 & 15 \\
\hline Fatehpur & & & 7.1 & 0.01 & 34 \\
\hline Bansbana & & & 10.4 & 0.00 & 42 \\
\hline Hatikanda & -5.5 & -35.9 & 16.0 & 0.19 & 2 \\
\hline Bansbana & -4.6 & -30.1 & 11.2 & 0.00 & 135 \\
\hline Bhabanipur & -4.3 & -27.8 & 8.2 & 0.01 & 1 \\
\hline Fatehpur & & & 2.2 & 0.00 & 27 \\
\hline Subarnapur & -4.9 & -32.0 & 3.9 & 0.00 & 54 \\
\hline Fatehpur & & & 3.8 & 0.00 & 108 \\
\hline Subarnapur & -4.7 & -30.3 & 23.1 & 0.00 & 82 \\
\hline Kurambelia & & & 3.7 & 0.00 & 24 \\
\hline Panpur & & & 23.1 & 0.02 & 25 \\
\hline Subarnapur & -4.4 & -28.6 & 8.9 & 0.00 & 37 \\
\hline Kurambelia & & & 4.5 & 0.00 & 30 \\
\hline Mobarekpur & & & 5.5 & 0.01 & 25 \\
\hline
\end{tabular}




$\begin{array}{lllll}\text { UG13 MB 28 } & 88.575 & 22.963 & 40 & \text { HTW } \\ \text { UG13 MUR 3 } & 88.548 & 22.972 & 40 & \text { HTW } \\ \text { WB11DS12 143 } & 88.604 & 22.958 & 43 & \text { HTW } \\ \text { Molla 2 } & 88.582 & 22.952 & 43 & \\ \text { UG13 BN 3 } & 88.583 & 22.925 & 43 & \text { HTW } \\ \text { UG12 BB 55 } & 88.598 & 22.963 & 43 & \text { HTW } \\ \text { UG13 UR 4 } & 88.572 & 22.969 & 46 & \text { HTW } \\ \text { UG13 BJ 2 } & 88.572 & 22.998 & 47 & \text { *HTW } \\ \text { WB11DS12 150 } & 88.599 & 22.950 & 48 & \text { HTW } \\ \text { WB11DS12 168 } & 88.602 & 22.953 & 49 & \text { SIW } \\ \text { UG13 UR 2 } & 88.574 & 22.979 & 49 & \text { HTW } \\ \text { UG13 UR 1 } & 88.574 & 22.979 & 49 & \text { HTW } \\ \text { UG13 BJ 1 } & 88.572 & 22.998 & 49 & \text { HTW } \\ \text { UG13 MB 25 } & 88.576 & 22.963 & 58 & \text { HTW } \\ \text { UG13 PN 10 } & 88.577 & 22.986 & 49 & \text { HTW } \\ \text { UG13 FP 4 } & 88.585 & 22.946 & 67 & \text { HTW }\end{array}$

\begin{tabular}{|c|c|c|c|c|c|}
\hline Mollabelia (North) & & & 3.9 & 0.22 & 2 \\
\hline Muragacha & -3.4 & -25.1 & 14.4 & 1.14 & 4 \\
\hline Nonaghata & & & 6.2 & 0.00 & 0 \\
\hline Mollabelia & & & 6.6 & 1.10 & 1 \\
\hline Bansbara & & & 6.1 & 0.00 & 1 \\
\hline Bamunberia & & & 44.5 & 12.36 & 15 \\
\hline Uttar Rajapur & & & 1.9 & 0.07 & 1 \\
\hline Bijra_Panchanantala & & & 2.0 & 0.00 & 19 \\
\hline Nonaghata & & & 3.4 & 0.00 & 18 \\
\hline Nonaghata & -3.6 & -25.8 & 9.2 & 0.43 & 1 \\
\hline Uttar Rajapur & & & 3.5 & 3.36 & 1 \\
\hline Uttar Rajapur & & & 4.6 & 4.90 & 1 \\
\hline Bijra_Panchanantala & & & 3.5 & 0.33 & 3 \\
\hline Panpur & & & 15.1 & 0.01 & 0 \\
\hline Nonaghata & & & 4.5 & 0.02 & 0 \\
\hline Muragacha & -3.6 & -24.8 & 22.1 & 5.26 & 1 \\
\hline Fatehpur & & & 3.4 & 0.03 & 1 \\
\hline Nonaghata & -4.5 & -27.5 & 2.9 & 0.01 & 0 \\
\hline Muragacha & -4.2 & -29.0 & 6.4 & 0.00 & 4 \\
\hline Fatehpur & & & 2.1 & 0.00 & 13 \\
\hline Mollabelia (South) & & & 2.0 & 0.00 & 15 \\
\hline Panpur & -4.4 & -28.9 & 4.4 & 1.37 & 0 \\
\hline Uttar Rajapur & & & 9.9 & 3.60 & 0 \\
\hline Fatehpur & & & 3.3 & 0.00 & 1 \\
\hline Muragacha & -3.8 & -25.2 & 23.6 & 1.07 & 2 \\
\hline Mollabelia (South) & & & 3.4 & 0.01 & 6 \\
\hline Mollabelia (South) & & & 2.6 & 0.00 & 10 \\
\hline Mollabelia (North) & & & 9.1 & 0.61 & 1 \\
\hline Mollabelia (North) & & & 5.4 & 0.59 & 1 \\
\hline Bansbara & & & 4.2 & 0.02 & 14 \\
\hline Fatehpur & & & 2.1 & 0.00 & 0 \\
\hline
\end{tabular}

Pleistocene Aquifers at $>70 \mathrm{~m}$ depth under Deep Palaeo-channels

$\begin{array}{lcccc}\text { UG13 AB 2 } & 88.571 & 22.938 & 79 & \text { HTW } \\ \text { UG13 BN 7 } & 88.583 & 22.924 & 98 & \text { *HTW } \\ \text { UG13 AB 10 } & 88.570 & 22.941 & 101 & { }^{*} \text { Mark II } \\ \text { UG13 SBN 10 } & 88.566 & 22.948 & 104 & \text { *Mark II } \\ \text { UG13 UR 14 } & 88.564 & 22.981 & 105 & \text { *Mark II } \\ \text { DOG } & 88.581 & 22.883 & 107 & \text { Mark II } \\ \text { BJR 3 } & 88.555 & 23.013 & 110 & \\ \text { UG13 SBN 13 } & 88.567 & 22.945 & 113 & \text { HTW } \\ \text { UG13 SON 12 } & 88.554 & 23.002 & 122 & \text { Mark II } \\ \text { WB11DS08 21 } & 88.609 & 22.953 & 122 & \text { HTW } \\ \text { UG13 SBN 2 } & 88.564 & 22.951 & 122 & \text { HTW } \\ \text { UG13 SKP 1 } & 88.567 & 22.911 & 122 & \text { HTW }\end{array}$

$\begin{array}{rrrrrrr}\text { Atbeharia } & -4.2 & -29.3 & 20.2 & 3.95 & 8 & 26 \\ \text { Bansbana } & -4.5 & -29.3 & 7.2 & 0.00 & 133 & 22 \\ \text { Atbeharia } & -4.7 & -30.2 & 14.2 & 3.36 & 72 & 27 \\ \text { Subarnapur } & -4.6 & -29.2 & 14.6 & 0.00 & 60 & 37 \\ \text { Uttar Rajapur } & -5.1 & -33.1 & 27.9 & 0.38 & 38 & 51 \\ \text { Dogachia } & -4.47 & 29.72 & 3.2 & 0.00 & 22 & 19 \\ \text { Bijra } & & & 5.9 & 0.00 & 16 & 35 \\ \text { Subarnapur } & -4.3 & -27.8 & 5.7 & 0.00 & 52 & 13 \\ \text { Sonakhali } & & & 4.4 & 0.31 & 10 & 17 \\ \text { Kuthipara } & -4.9 & -32.3 & 4.7 & 0.02 & 13 & 23 \\ \text { Subarnapur } & -4.9 & -31.7 & 6.0 & 0.05 & 16 & 29 \\ \text { Sri krishnapur } & -4.7 & -32.1 & 3.1 & 0.00 & 29 & 14\end{array}$




\begin{tabular}{|c|c|c|c|c|c|c|c|c|c|c|c|}
\hline UG13 SB 10 & 88.636 & 22.960 & 122 & HTW & Subuddipur & & & 15.9 & 0.00 & 33 & 32 \\
\hline UG13 GTR 18 & 88.602 & 22.999 & 122 & HTW & Dakshin Panchpota & & & 4.0 & 0.00 & 102 & 18 \\
\hline BM 2 & 88.559 & 22.925 & 122 & STW & Brahmanpur & -4.12 & 28.97 & 2.5 & 0.01 & 36 & 23 \\
\hline PRB 1 & 88.545 & 22.898 & 122 & HPW & Netai Ghosh, village ? & -4.06 & 28.20 & 4.3 & 0.00 & 36 & 29 \\
\hline UG12 JK 82 & 88.613 & 22.962 & 122 & HTW & Julkarampur & & & 24.3 & 0.00 & 41 & 50 \\
\hline UG12 JK 231 & 88.618 & 22.957 & 122 & HTW & Julkarampur & & & 17.5 & 0.00 & 64 & 39 \\
\hline UG12 BB 81 & 88.600 & 22.968 & 122 & HTW & Bamunberia & & & 3.9 & 0.00 & 100 & 29 \\
\hline UG12 BB 11 & 88.599 & 22.962 & 126 & ${ }^{*} \mathrm{HTW}$ & Bamunberia & & & 2.7 & 0.00 & 59 & 14 \\
\hline BHK & 88.591 & 22.873 & 128 & Mark II & Bhurkundra & -3.64 & 23.54 & 5.6 & 0.01 & 33 & 24 \\
\hline MSD 1 & 88.587 & 23.013 & 134 & HPW & Mohishdang & -4.15 & 29.15 & 2.4 & 0.01 & 103 & 22 \\
\hline WB12 DS06 216 & 88.609 & 22.954 & 134 & & Kuthipara & -4.9 & -31.5 & 22.0 & 0.03 & 1 & 82 \\
\hline UG 13 SON 9 & 88.557 & 23.016 & 134 & HTW & Sonakhali/ Baksha & -4.5 & -29.9 & 6.7 & 0.00 & 40 & 32 \\
\hline UG13 GTR 22 & 88.584 & 23.025 & 134 & HTW & Ghetugachi & & & 3.5 & 0.05 & 59 & 13 \\
\hline WB11DS12 14 & 88.604 & 22.960 & 134 & HTW & Nonaghata & -4.4 & -30.6 & 16.1 & 0.03 & 61 & 65 \\
\hline UG13 SBN 12 & 88.567 & 22.945 & 134 & HTW & Subarnapur & -5.2 & -34.0 & 4.3 & 0.00 & 120 & 20 \\
\hline UG13 GTR 17 & 88.603 & 23.000 & 134 & HTW & Dakshin Panchpota & & & 4.0 & 0.00 & 134 & 17 \\
\hline UG13 GTR 16 & 88.601 & 23.002 & 134 & HTW & Dakshin Panchpota & & & 4.1 & 0.00 & 147 & 17 \\
\hline UG13 SBN 11 & 88.565 & 22.947 & 134 & HTW & Subarnapur & -3.6 & -25.5 & 34.9 & 1.51 & 157 & 48 \\
\hline UG13 JB 1 & 88.635 & 22.975 & 134 & HTW & Jalkarbhomra & -4.8 & -30.2 & 12.8 & 0.00 & 184 & 48 \\
\hline WB13 SK 37 & 88.644 & 22.954 & 137 & HTW & Mahadebpur & & & 13.7 & 0.01 & 90 & 29 \\
\hline 2014 SON 11b & 88.554 & 23.002 & 140 & HPW & Sonarkali & -4.4 & 29.59 & 4.3 & 2.04 & 9 & 23 \\
\hline UG13 SBN 6 & 88.564 & 22.950 & 143 & HTW & Subarnapur & -4.9 & -31.2 & 4.8 & 0.00 & 51 & 31 \\
\hline UG13 MD1 & 88.609 & 22.913 & 146 & Mark II & Mali Danga & & & 3.0 & 0.00 & 57 & 15 \\
\hline UG 13 SON 1 & 88.558 & 23.015 & 152 & Mark II & Sonakhali/ Baksha & -4.23 & -28.7 & 6.0 & 0.01 & 30 & 29 \\
\hline UG 13 SON 10 & 88.555 & 23.013 & 152 & Mark II & Sonakhali/ Baksha & -4.56 & -30.2 & 4.5 & 0.00 & 13 & 24 \\
\hline UG13 BIR 11 & 88.542 & 22.995 & 152 & Mark II & Birohi & & & 2.8 & 0.03 & 65 & 17 \\
\hline UG13 DB 2 & 88.658 & 22.945 & 152 & Mark II & Dasberia & & & 1.5 & 0.02 & 51 & 9 \\
\hline UG13 DKD 2 & 88.606 & 22.938 & 152 & Mark II & Dakshin dattapara & & & 3.0 & 1.25 & 3 & 21 \\
\hline UG13 DKD 9 & 88.600 & 22.944 & 152 & Mark II & Dakshin dattapara & & & 4.8 & 0.00 & 26 & 21 \\
\hline UG13 GN 22 & 88.678 & 22.959 & 152 & Mark II & Gopinathpur & & & 212.4 & 0.00 & 95 & 762 \\
\hline UG13 GN 24 & 88.674 & 22.957 & 152 & Mark II & Gopinathpur & & & 184.9 & 0.00 & 93 & 663 \\
\hline UG13 GTR 11 & 88.595 & 23.016 & 152 & Mark II & Ramkestopur & -4.71 & -31.0 & 4.4 & 0.01 & 76 & 18 \\
\hline UG13 GTR 13 & 88.602 & 23.005 & 152 & Mark II & Dakshin Panchpota/Kadambagachi & -4.67 & -30.2 & 3.2 & 0.00 & 113 & 17 \\
\hline UG13 GTR 15 & 88.603 & 23.003 & 152 & Mark II & Dakshin Panchpota & -4.79 & -30.6 & 3.5 & 0.00 & 93 & 17 \\
\hline UG13 GTR 19 & 88.599 & 23.000 & 152 & Mark II & Dakshin Panchpota & -4.52 & -30.6 & 3.4 & 0.00 & 125 & 18 \\
\hline UG13 GTR 20 & 88.598 & 23.001 & 152 & Mark II & Dakshin Panchpota & -4.68 & -29.9 & 4.4 & 0.00 & 83 & 20 \\
\hline UG13 GTR 23 & 88.604 & 23.011 & 152 & Mark II & Kadambagachi & -4.72 & -30.7 & 6.1 & 0.00 & 98 & 23 \\
\hline UG13 GTR 24 & 88.601 & 23.006 & 152 & Mark II & Dakshin Panchpota & -4.80 & -30.9 & 4.4 & 0.00 & 28 & 20 \\
\hline UG13 GTR 4 & 88.588 & 23.020 & 152 & Mark II & Ramkestopur(Gotera) & -4.53 & -30.2 & 2.8 & 0.01 & 82 & 16 \\
\hline UG13 JB 10 & 88.635 & 22.974 & 152 & Mark II & Jalkarbhomra & -4.56 & -30.5 & 66.5 & 0.02 & 65 & 232 \\
\hline UG13 JB 3 & 88.634 & 22.975 & 152 & Mark II & Jalkarbhomra & -4.68 & -30.0 & 68.3 & 0.00 & 50 & 225 \\
\hline UG13 JB 7 & 88.631 & 22.977 & 152 & Mark II & Jalkarbhomra & -4.91 & -31.9 & 35.3 & 0.00 & 35 & 122 \\
\hline UG13 PD 10 & 88.622 & 22.898 & 152 & Mark II & Payradanga/Parulia & -4.85 & -31.5 & 2.4 & 0.00 & 49 & 14 \\
\hline UG13 PK 12 & 88.564 & 22.936 & 152 & Mark II & Panchkaun & -4.83 & -30.3 & 3.8 & 0.00 & 326 & 30 \\
\hline UG13 PN 19 & 88.599 & 22.980 & 152 & Mark II & Panpur & -4.90 & -30.8 & 6.8 & 0.00 & 20 & 39 \\
\hline UG13 SBN 14 & 88.561 & 22.956 & 152 & Mark II & $\begin{array}{l}\text { Haringhata-Jaguli Rd } \\
\text { Kaltala/Subarnapur }\end{array}$ & -4.38 & -29.2 & 12.1 & 0.01 & 32 & 47 \\
\hline UG13 SKP 6 & 88.568 & 22.913 & 152 & Mark II & Sri krishnapur & -4.56 & -29.2 & 3.6 & 0.00 & 26 & 15 \\
\hline UG13 GTR 3 & 88.585 & 23.021 & 152 & Mark II & Ramkestopur(Gotera) & -4.7 & -30.7 & 4.1 & 0.00 & 77 & 15 \\
\hline
\end{tabular}




$\begin{array}{lrlllrrrrrrrr}\text { AYP } & 88.546 & 22.986 & 165 & \text { Mark II } & \text { School well, Digha, Harighata } & -5.37 & -34.3 & 1.9 & 0.00 & 275 & 16 \\ \text { BDK } & 88.637 & 22.908 & 165 & \text { Mark II } & \text { School, Harighata } & -3.08 & 21.35 & 3.2 & 0.00 & 122 & 29 \\ \text { HPK } & 88.613 & 22.950 & 165 & \text { Mark II } & \text { School, Haripurkuria } & -4.74 & 30.61 & 12.9 & 0.03 & 1 & 63 \\ \text { HRG } & 88.568 & 22.962 & 165 & \text { Mark II } & \text { Harighata } & -3.68 & 21.70 & 21.5 & 0.17 & 3 & 85 \\ \text { NYP } & 88.558 & 22.974 & 165 & \text { Mark II } & \text { Harighata, Dipankar's well } & -4.44 & 31.62 & 1.8 & 0.02 & 41 & 12 \\ \text { UG12 JK 283 } & 88.615 & 22.961 & 195 & \text { HTW } & \text { Julkarampur } & -3.82 & 23.29 & 480.0 & 0.01 & 3 & 1778 \\ \text { DR 1 } & 88.566 & 22.972 & 237 & \text { Mark II } & \text { Harighata } & -2.88 & 18.90 & 33.8 & 34.51 & 13 & 125 \\ \text { SL 1 } & 88.564 & 22.962 & 249 & \text { Mark II } & \text { Harighata } & -3.32 & 20.39 & 30.9 & 17.25 & 2 & 118\end{array}$

Holocene Aquifers 35 - 70 mbgl in Deep Palaeo-channels

Others lacking stable isotope data can be found in Ghosal et al. 2015

\begin{tabular}{|c|c|c|c|c|c|c|c|c|c|c|}
\hline UG13 JB 6 & 88.633 & 22.976 & 37 & HTW & Jalkarbhomra & -6.0 & -38.6 & 16.7 & 3.15 & 28 \\
\hline UG13 PD 6 & 88.621 & 22.898 & 37 & HTW & Payradanga/Parulia & -5.3 & -35.6 & 35.6 & 15.95 & 5 \\
\hline UG13 AB 8 & 88.571 & 22.938 & 37 & HTW & Atbeharia & -4.9 & -33.6 & 31.1 & 10.68 & 3 \\
\hline UG13 GTR 2 & 88.600 & 23.000 & 37 & HTW & Panchpota & -4.7 & -29.3 & 5.8 & 0.00 & 201 \\
\hline UG13 GTR 10 & 88.594 & 23.017 & 37 & HTW & Ramkestopur & -4.4 & -27.8 & 70.5 & 11.83 & 62 \\
\hline UG13 SKP 5 & 88.568 & 22.913 & 37 & HTW & Sri krishnapur & -3.4 & -24.4 & 23.9 & 13.14 & 41 \\
\hline UG13 GTR 8 & 88.593 & 23.018 & 37 & HTW & Ramkestopur/Gotera/Kadamgachi & -3.1 & -20.8 & 7.2 & 0.00 & 42 \\
\hline UG13 PK 3 & 88.566 & 22.934 & 37 & HTW & Panchkaun & -2.6 & -17.8 & 7.8 & 0.00 & 93 \\
\hline UG13 BN 13 & 88.581 & 22.925 & 40 & *HTW & Bansbana & -4.4 & -27.9 & 17.7 & 0.00 & 88 \\
\hline UG13 PK 9 & 88.566 & 22.933 & 43 & HTW & Panchkaun & -3.2 & -21.9 & 7.6 & 0.06 & 18 \\
\hline UG13 BIR 5 & 88.541 & 22.991 & 46 & HTW & Birohi & -5.7 & -37.6 & 11.8 & 0.01 & 103 \\
\hline UG13 BIR 2 & 88.549 & 22.991 & 46 & HTW & Birohi & -5.7 & -37.7 & 16.4 & 10.51 & 53 \\
\hline UG13 BIR 10 & 88.547 & 22.991 & 46 & HTW & Birohi & -5.7 & -36.9 & 20.4 & 1.65 & 35 \\
\hline UG13 BIR 9 & 88.546 & 22.991 & 46 & HTW & Birohi & -5.6 & -36.7 & 19.6 & 1.50 & 61 \\
\hline UG 13 SON 7 & 88.558 & 23.016 & 46 & HTW & Sonakhali/ Baksha & -5.0 & -32.5 & 33.6 & 0.00 & 31 \\
\hline UG13 BHA 10 & 88.548 & 22.927 & 46 & HTW & Bhabanipur & -4.8 & -30.3 & 73.4 & 27.56 & 6 \\
\hline WB11DS12 169 & 88.608 & 22.954 & 46 & SIW & Kuthipara & -3.9 & -27.3 & 5.5 & 0.65 & 114 \\
\hline UG13 PK 8 & 88.566 & 22.933 & 46 & HTW & Panchkaun & -3.7 & -24.8 & 6.7 & 0.00 & 22 \\
\hline UG13 PK 1 & 88.566 & 22.933 & 46 & HTW & Panchkaun & -3.4 & -23.2 & 6.0 & 0.01 & 40 \\
\hline BM 1 & 88.559 & 22.925 & 46 & SIW & Bizra & -4.26 & $29.12^{-}$ & 3.5 & 0.01 & 43 \\
\hline WB11DS12 170 & 88.606 & 22.953 & 49 & SIW & Kuthipara & -4.2 & -27.8 & 2.5 & 0.02 & 92 \\
\hline UG13 MUR 7 & 88.548 & 22.973 & 49 & HTW & Muragacha & -3.8 & -25.2 & 33.3 & 3.44 & 2 \\
\hline PRB 2 & 88.545 & 22.898 & 49 & HPW & Netai Ghosh, ? & -4.28 & 29.30 & 12.2 & 0.00 & 65 \\
\hline WB11DS08 29 & 88.610 & 22.952 & 52 & HTW & Kuthipara & -4.1 & -26.1 & 2.3 & 0.04 & 86 \\
\hline UG13 SON 8 & 88.558 & 23.016 & 52 & HTW & Sonakhali/ Baksha & 0.0 & -4.5 & 20.9 & 0.00 & 10 \\
\hline UG13 PD 4 & 88.621 & 22.898 & 53 & HTW & Payradanga/Parulia & -4.3 & -30.1 & 19.4 & 13.76 & 1 \\
\hline UG13 AB 4 & 88.570 & 22.938 & 55 & SIW & Atbeharia & -4.3 & -29.1 & 33.8 & 0.85 & 26 \\
\hline UG13 BN 10 & 88.581 & 22.924 & 55 & HTW & Bansbana & -4.2 & -27.9 & 40.0 & 0.00 & 123 \\
\hline UG13 BN 12 & 88.581 & 22.925 & 58 & HTW & Bansbana & -4.3 & -27.1 & 19.8 & 0.00 & 257 \\
\hline UG13 GTR 21 & 88.583 & 23.022 & 58 & HTW & Gotera & -3.6 & -24.2 & 20.1 & 5.23 & 27 \\
\hline UG13 BN 11 & 88.581 & 22.925 & 58 & HTW & Bansbana & -3.4 & -23.5 & 43.8 & 2.85 & 117 \\
\hline $\mathrm{PH} 2$ & 88.565 & 22.929 & 61 & STW & Panchkauni & -3.89 & 25.61 & 4.0 & 0.02 & 198 \\
\hline UG13 SKP 4 & 88.568 & 22.912 & 61 & HTW & Sri krishnapur & -3.1 & -24.3 & 26.9 & 4.79 & 28 \\
\hline MSD 2 & 88.589 & 23.013 & 64 & SIW & Mohishdang & -3.57 & 25.53 & 5.3 & 0.00 & 95 \\
\hline
\end{tabular}

